\title{
Control of acid mine drainage from an abandoned mine in Morocco by using cement kiln dust and fly ash as amendments
}

\author{
S. Nfissi ${ }^{1}$, S. Alikouss ${ }^{1}$, Y. Zerhouni ${ }^{1}$, R. Hakkou ${ }^{2}$, M. Benzaazoua ${ }^{3,4}$, H. Bouzahzah ${ }^{3}$ \\ 1.Laboratory of Ancient Chain Geodynamics, Department of Geology, University of Hassan II-Casablanca, \\ Av. Hassan II - B.P 7955, Casablanca, Morocco. \\ 2. LCME, Faculty of Sciences and Technology, Cadi Ayyad University, AbdelkarimElkhattabi Avenue, Gueliz, \\ P.O. Box 549, Marrakech, Morocco. \\ 3.IDRC Research Chair in Management and Stabilization of Mining and Industrial Wastes, University of Quebec Abitibi \\ Témiscamingue, 445 Boul. University, Rouyn-Noranda, QC J9X 5E4, Canada. \\ 4. INSA Lyon, Laboratory of Civil and Environmental Engineering, Bât. Sadi Carnot, 9, rue de la physique, 69621 \\ Villeurbanne cedex, France.
}

Received 15May 2015, Revised 17Jul 2017, Accepted 20 Jul 2017

\section{Keywords}

$\checkmark$ Acid mine drainage;

$\checkmark$ Alkali amendments;

$\checkmark$ CKD;

$\checkmark$ FA;

$\checkmark$ Environment;

$\checkmark$ Kettara;

\section{S Nfissi}

snfissi@gmail.com

$+(212) 0610345620$

\begin{abstract}
Acid mine drainage (AMD) is one of the major problems of the mining industry that is causing prominent environmental damages. It occurs naturally when sulfide tailings oxidize and generate an acidic leachate containing leachate loaded with heavy metals $(\mathrm{Pb}, \mathrm{Fe}, \mathrm{Zn}, \mathrm{Cu}, \mathrm{Cd}$, As ...) and other toxic compounds.During mining activities and after mine closure, storage of discharges places (waste rock piles and tailings parks) might be responsible for the production of acid leachate which will have adverse consequences on the environment.The Kettara abandoned mine (Morocco) has produced from 1965 to 1982 more than 3 Mt of mine wastes that are rich in sulfides (pyrrhotite and pyrite). The physicochemical characterization of these mine wastes confirmed their strong potential to produce Acid Mine drainage with a pH varying between 2.9 and 1.5.In order to control AMD in Kettara mine site, AMD neutralization tests were undertaken in the laboratory using two types of alkaline industrial byproducts as amendments. The latter consisted of alkaline Fly Ash (FA) from the thermal power plant of JorfLasfar in El Jadida and Cement Kiln Dust (CKD), from Lafarge cement of Bouskoura near the city of Casablanca, Morocco. The tests in leaching columns objectives are to determine the ratios of CKD, FA and residues who may neutralize the phenomenon of AMD in Kettara site. The leaching columns tests show that the use the industrial by-products allows increase the leachate $\mathrm{pH}$ to values of about 6.5 and 7.13 and the substantial reduction of metals concentrations such as Fe (from 0.01 to $<0.12 \mathrm{mg} / \mathrm{L}$ ) and $\mathrm{Cu}(<0.02 \mathrm{mg} / \mathrm{L}$ ). The AMD from Kettara mine tailings could be reduced by adding amendments composed of $80 \%$ of CKD and $20 \%$ of FA.This method of treatment with CKD and FA allow recycling and valorization of industrial waste cement plants and thermal power plants.
\end{abstract}

\section{Introduction}

All along mining and ore processing, mine wastes produced can cause significant contamination of mine drainage [1-3]. Oxidation of sulfide minerals (pyrite...) of their oxidation products can produce acid mine drainage (AMD), which may be drained into local waterways and groundwater, for then elevated concentrations of $\mathrm{SO}_{4}^{2-}$ and contaminants such as $\mathrm{Fe}, \mathrm{Al}, \mathrm{Mn}, \mathrm{Pb}, \mathrm{Zn}, \mathrm{Cu}, \mathrm{Cd}$, depending on the geology and mineralogy of the mine site.

Several mitigation methods can be used to prevent and stop the production of AMD in tailings such as effluent treatment [4], underwater deposit [5, 6], recoveries capillary barrier effects [7, 8], environmental desulphurization [9-15]) and alkaline amendment [16-18]. The latter process consists in mixing the residues AMD generators with alkaline materials in order to limit the oxidation of sulfide and neutralize the acidity generated. 
Generally, the best solution to an AMD problem is to prevent acid generation; using an oxygen and/or water infiltration barrier $[19,6]$. An alternative approach is to add sufficient alkaline material to neutralize the acidity and immobilize the metals [20, 21]. A lot of products have been used as an amendment like: (1) fly ash produced by power plants [22-30, 16], (2) cement kiln dust (CKD) produced in Portland cement manufacturing [30-32, 16], (3) red mud produced by the aluminum industry [27], (4) paper pulp [33]. Other projects aims to valorize mine tailings (ex. Jerada region) [34].

The rehabilitation scenario, being investigated at the Kettara mine involves using fine alkaline phosphate waste exploitation of Moroccan phosphates (APW) as both an amendment [17] and a 'store and release' (SR) cover [35].

The present study report the results of laboratory column leaching tests thus assessing the amendment aspect of the cement kiln dust and fly ash. We aim at first the AMD prevention and valorization of these two products considered as industrial waste. The pilot site, located north of Marrakech, is in the core of the central Jebilet Mountains (Figure 1). The Jebilet massif is one of the largest Palaeozoic massifs of the Hercynian fold belt of Morocco [36].

The interest of using CKD and FA to control AMD generation is threefold: $i$ ) remove the storage areas around the production plants and reduce the risk of environmental contamination through leaching of metals ii) neutralize the acidic mine tailings and make use of the high neutralization potential of CKD and FA [37, 16, 30], iii) stabilize heavy metals by using CKD that releases by dissolution high concentrations of potassium, sulfate and leads causing precipitation of secondary minerals "reservoirs" such as ettringite, CSH and gypsum [38-40, 30]. The Fly ash has hydraulic or pozzolanic properties that increase the effect of binder. iiii) increase the effect of binder by using Fly ash who has hydraulic or pozzolanic properties appropriate [41].

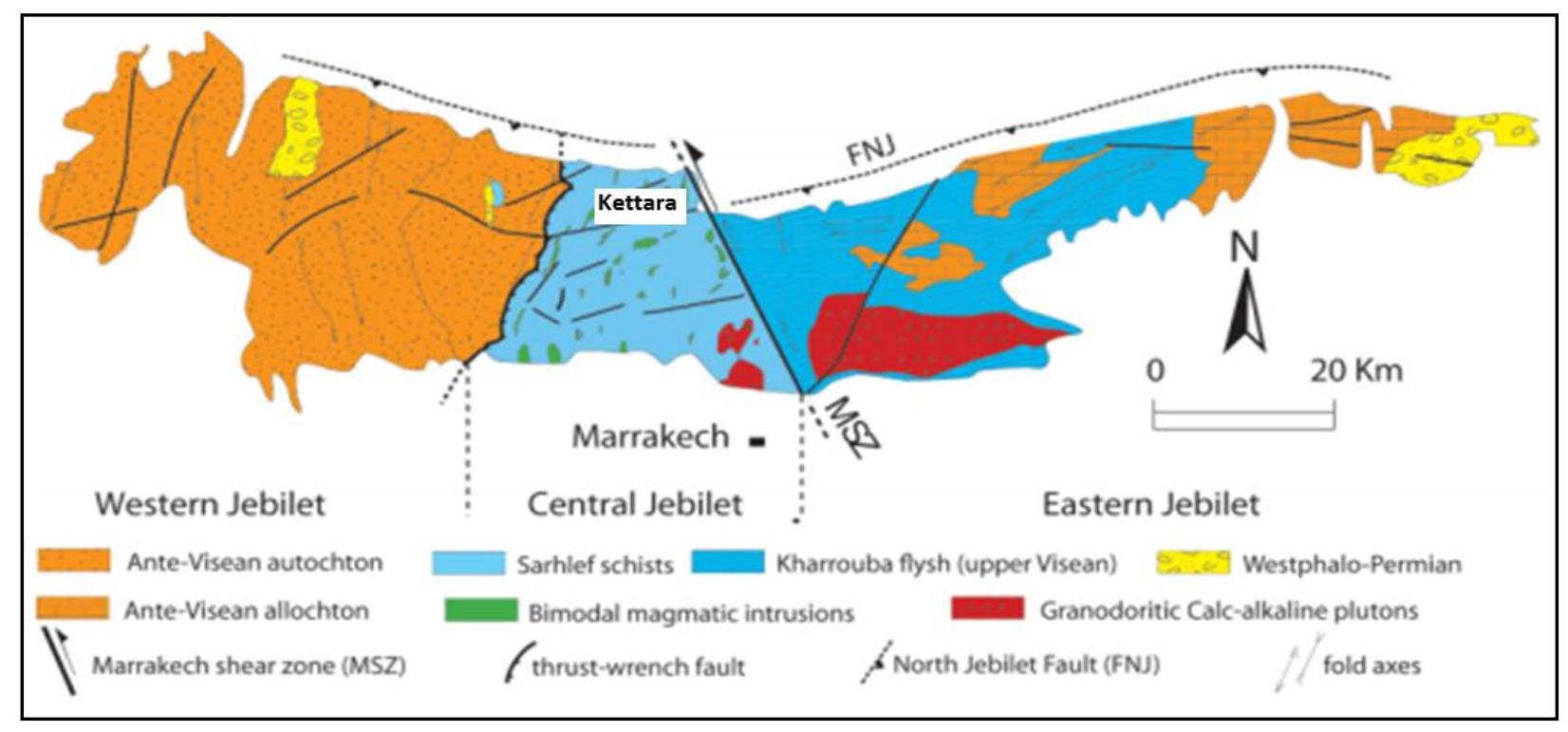

Figure 1: Simplified geological map of the Jebilet massif (modified after Huvelin [42] in [43]).

\section{Materials}

\subsection{Tk: Tailings Kettara}

The Kettara mine site is located approximately $32 \mathrm{Km}$ northwest of Marrakech ( $31^{\circ} 52^{\prime} 15$ "N 8० 10'31" W) [44], on the edge of the road $\mathrm{N}^{\circ} 9$ leading to the coastal town of Safi (Figure 2a). The mine is currently one of several abandoned mine sites in Morocco producing AMD, that contaminates soils [45], and surface water and groundwater [46, 47] (Figure 2c). More than 3 million tons of mine wastes deposited on the surface of the Kettara site without any concern for environmental consequences have generated significant AMD for more than 30 years.

Tailings were stockpiled in a main pond, but also in a dyke, and in smaller piles over an area of approximately 16 ha. The abandoned Kettara Mine generates acidic leachates with a pH between 2.9 and 1.5 [46, 48].

The acidification potential (AP) of that is between 51 and $453 \mathrm{Kg} \mathrm{CaCO}_{3} / \mathrm{t}$ while the net of neutralization potential (NNP) ranges from -453 to $-22.5 \mathrm{Kg} \mathrm{CaCO}_{3} / \mathrm{t}$ [46]. The permeability test of samples has provided permeability between $4.910^{-2} \mathrm{~cm} / \mathrm{s}$ and $1.110^{-1} \mathrm{~cm} / \mathrm{s}$, so these tailing are classified into the range of perfectly permeable materials [30]. 


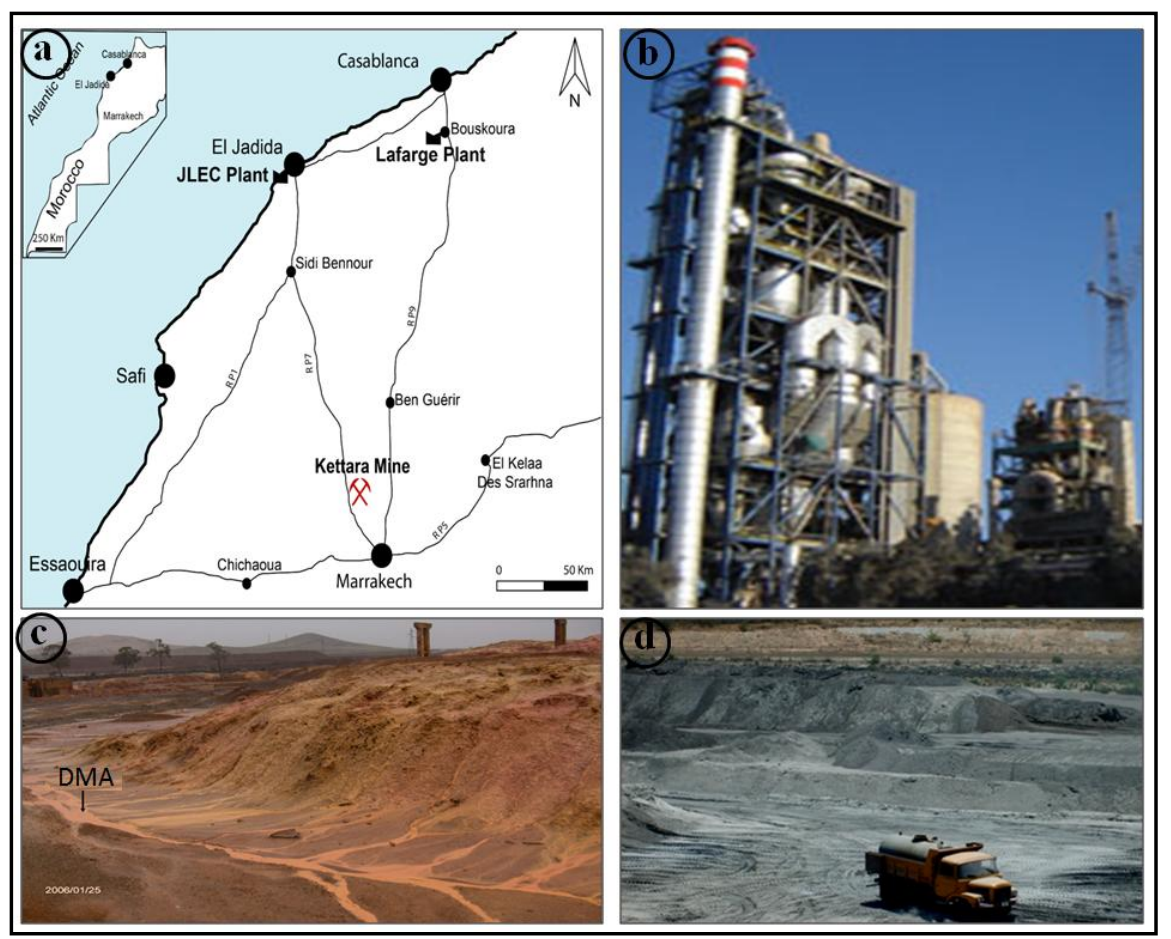

Figure 2: a) Simplified map showing the location of Kettara mine, JorfLasfar Power Plant (JLEC) and Lafarge Cement Plant, b) Lafarge plant (Bouskoura, Casablanca), c) Runoff of acid surface water in Kettara, d) Fly ash storage area (JorfLasfar).

Effluent water samples elevated concentrations of $\mathrm{Pb}, \mathrm{As}, \mathrm{Co}, \mathrm{Zn}, \mathrm{Cu}$ and $\mathrm{Cr}$. The Iron, which could be associated with pyrrhotite and pyrite, is present in these solid tailings with relatively large amounts [46, 48]. These High concentrations of some toxic metals contaminate soil, aquatic ecosystems, wildlife as well as human health [48]. This mine site remains hazardous. It generates a large AMD in the tailings park [46, 48] and therefore requires control.Tailings samples from the Kettara mine (TK) are corresponding for unweathered coarse tailings. They were collected at a depth of $1 \mathrm{~m}$ from an exploratory trench which was excavated in the 15 $\mathrm{m}$ high dyke. Sampling location is indicated on Figure 3.

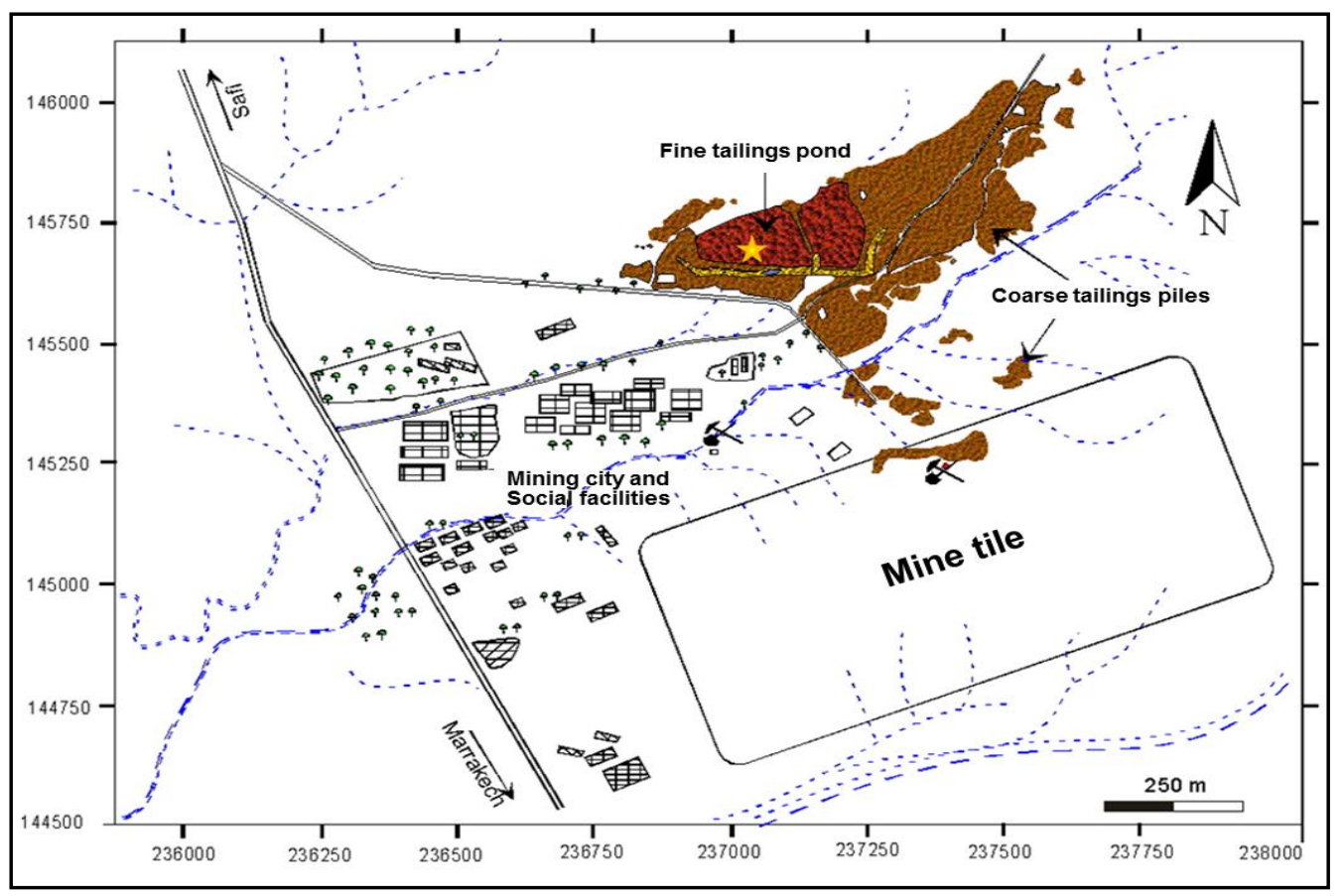

Figure 3: Sample location of tailing chosen for kinetic test columns. 


\subsection{Alkaline material: $C K D$ and $F A$}

At first, a physicochemical and mineralogical study of fly ash and cement kiln dust was carried out [30] to evaluate the potential neutralization of these acid generators residues and define the most appropriate scenarios for the control of the AMD phenomenon in Kettara site.

Cement Kiln Dust (CKD) and Fly Ash (FA) are industrials by-products produced in Morocco with large quantities; they can be an alternative to mitigate the AMD generated in the Kettara mine.

The CKD is dust fine-grained highly alkaline derived from cement kiln exhaust gas by air pollution control devices.

The CKD sample is taken from Lafarge Cement Plant, Bouskoura near the city of Casablanca (Figure 2a, 2b). It is a powder composed mainly of micrometer-sized particles that accumulated on the electrostatics filters of the rotary kilns during production of cement clinker [40]. Calcite is the majority mineral which composes CKD, followed by lime and anhydrite[30].

About the FA, it is a fine grey powder consisting mostly of spherical glassy particles that are produced as a byproduct in coal fired power stations. The FA used in this study is derived from the JorfLasfar Energy Company (JLEC) near the town of El Jadida (Figure 2a). About 400000 Mt of FA are produced annually [49](Figure 2d). Those resulting from the combustion of bituminous coal are characterized by low $\mathrm{CaO}$ content.

These alkaline materials are highly impermeable; they generate the formation of a barrier layer which will limit the infiltration of acid waters [50]. The study from Nfissi and al. [30] showed a high net neutralization potential of these materials that are in the range of $900.63 \mathrm{~kg} \mathrm{CaCO}_{3} / \mathrm{t}$ for the CKD and $243.75 \mathrm{~kg} \mathrm{CaCO}_{3} / \mathrm{t}$ for the FA.

Recent studies have shown that CKD could be consolidated and stabilized when used in mixture with amount of fly ash and/or other various materials [51]. Experimental work in the field [52] and/or laboratory [53] showed that the effectiveness of CKD increases in combination with other cementitious materials such as fly ash, which have pozzolanic or hydraulic properties that enhance effect of binder [41]. Thus CKD and FA are suitable materials and their mixture can be used as a cover layer and/or amendment.

The focus of this paper is to understand the effect of industrial by-products composed of cement kiln dust (CKD) and fly ash (FA) to mitigate the impact of the AMD in the Kettara site (Central Jebilets, Morocco). To reach this objective, a quantitative and qualitative study should perform in order to identify the most suitable protocol to stabilize the mine tailing of Kettara.

\section{Methods (Column leaching tests)}

Preliminary column tests were performed to evaluate the effect of alkaline materials on the tailings in small scale before starting testing on a larger scale on columns of standard size [54].

The leachate tests were carried using $14 \mathrm{~cm}$ in height and $5 \mathrm{~cm}$ diameter in small columns (Figure 4). They will identify the proportions of the amendments that lead to efficient neutralization of mine tailings of Kettara. The seven columns of kinetic tests consist of $2 / 3$ of tailings (200g) mixed with $1 / 3$ (100g) of amendment (CKD and/or FA). The proportions of CKD and FA vary from one test to another (Figure 4).

The results from the humidity cell tests, of a previous study Hakkou et al. [55], were teken as reference of the geochemical behavior of tailings without an amendment. These results are considered as proof to track the evolution of leachate quality after amendment.

Figure 3 shows that the column 1 was first filled by Kettara tailings (TK) mixed with the CKD alone. Column 2 consisted of the Kettara mine tailings mixed with amendment composed of $90 \%$ of CKD and 10\% of FA. Column 3 contained Kettara mine tailings mixed with $80 \%$ of CKD and $20 \%$ of FA. Concerning column 4, 70\% of CKD and 30\% of FA were added to Kettara tailings. In Column 5, 60\% of CKD and 40\% of FA were mixed up with the Kettara mine tailings. For Column 6, the proportion of the amendments was 50\% of CKD and 50\% of FA. Finally, column 7 was similar to column 1; the only difference being the addition of FA to Kettara mine tailings instead of CKD. Each column was flushed with approximately $100 \mathrm{ml}$ of distilled water on the day 7 , 10, and 15 and then all columns were left until the day 536 to evaluate the long term effect. The columns bottoms were equipped with a geotextile and water outlet to collect leachate. The water percolation time in each column was measured using a stopwatch.

The effluent obtained from the columns tests were filtered through a $0.45 \mu \mathrm{m}$ nylon filter and were split into two subsamples. The first was acidified with $\mathrm{HNO}_{3}$ (to avoid metal precipitation) for metals analysis and was refrigerated at $4^{\circ} \mathrm{C}$. The second (un-acidified) was used for the analyses of total alkalinity and total acidity. The leachates were analyzed by ICP-AES (Perkin-Elmer Optima DV 7000 ICP-OES, relative precision of 5\%) for major elements, minor elements and specific metals. Water $\mathrm{pH}$ and conductivity measurements, by using a $\mathrm{pH}-$ meter type (pH/Ion 510, Bench pH meter) and by a conductivity meter type (con510, Bench conductivity), were 
performed on freshly collected leachate samples. The alkalinity of untreated and treated AMD (expressed in $\mathrm{mgCaCO}_{3} / \mathrm{L}$ ) was obtained by titration of non-filtered sample with sulfuric acid $0.02 \mathrm{~N}$ (precision of $1 \mathrm{mg}$ $\mathrm{CaCO}_{3} / \mathrm{L}$ ), and the acidity by titration of non-filtered sample with sodium hydroxide $0.1 \mathrm{~N}$ (precision of $1 \mathrm{mg}$ $\left.\mathrm{CaCO}_{3} / \mathrm{L}\right)[57]$.

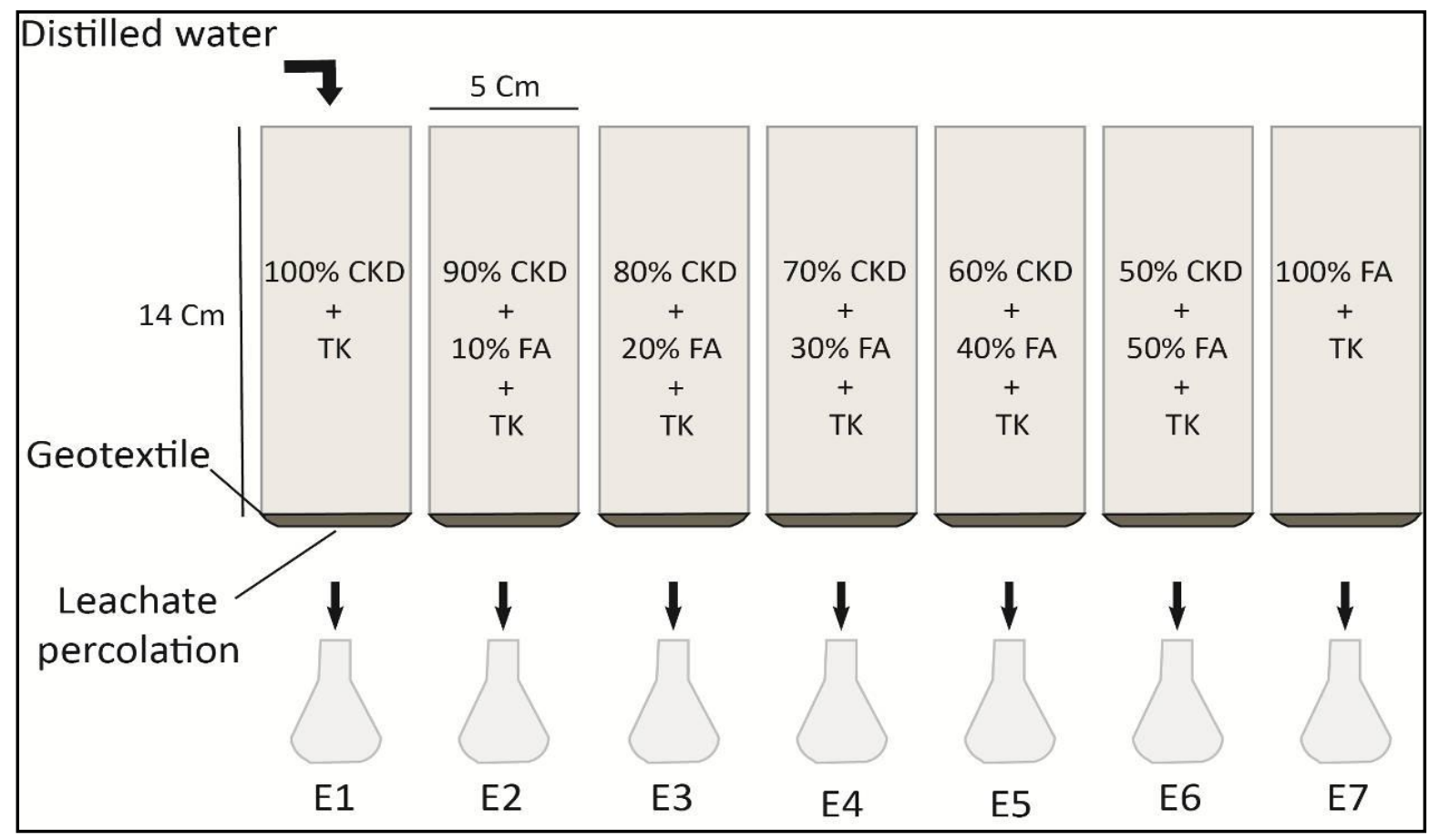

Figure 4: Schematic representation of the leaching columns.

\section{Results and Discussion}

The seven column experiments kinetic tests are compared to the test in wet reference cells [55] which contain only residues from Kettara. Percolation time measured during leaching shows that the mixtures of E2 and E3 have a high retention power (Figure 4). The flow of leachate takes place approximately one hour after the rinse. Variations in $\mathrm{pH}$, conductivity, acidity and alkalinity are shown as a function of time in the column leaching experiment (Figure 5).

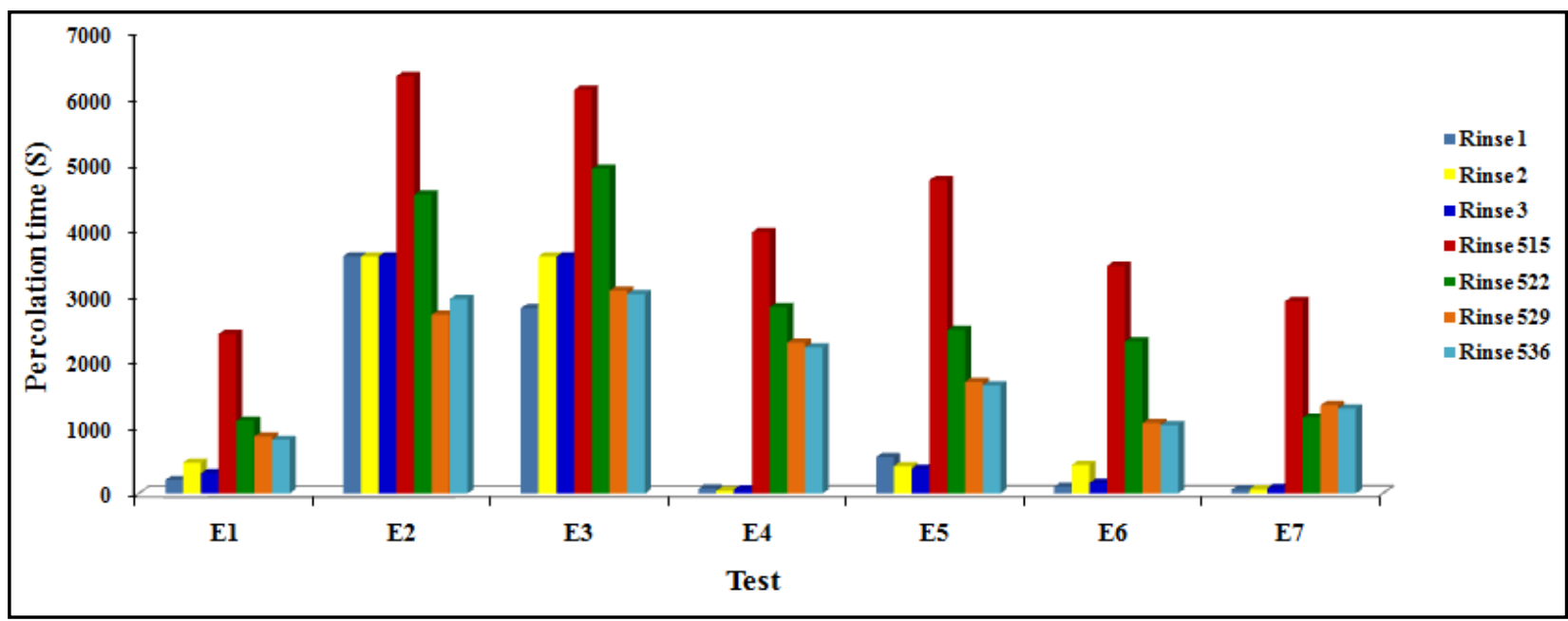

Figure 5: Percolation time kinetic tests.

The leachates from the mixtures containing high concentrations of CKD had higher $\mathrm{pH}$ values than those achieved with the FA. This is not surprising since CKD contained highly reactive soluble CaO (Figure 6 and Table 1). 
Table 1: Chemical composition of the leachate of the seven columns (mg/L).

\begin{tabular}{|c|c|c|c|c|c|c|c|c|}
\hline & \multicolumn{7}{|c|}{ Sample } \\
\hline & & E1 & E2 & E3 & E4 & E5 & E6 & E7 \\
\hline \multirow{7}{*}{$\mathrm{Ca}$} & $10 \mathrm{~d}$ & 238.4 & 212.05 & 451 & 125 & 549.35 & 592.4 & $<\mathrm{LD}$ \\
\hline & $15 \mathrm{~d}$ & 522.4 & 595.95 & 261.15 & 382.85 & 619.1 & 666.9 & 499.05 \\
\hline & $172 d$ & $<0.02$ & $<0.02$ & $<0.02$ & $<0.02$ & $<0.02$ & $<0.02$ & $<0.02$ \\
\hline & $515 d$ & 285 & 122 & 202 & 107 & 479 & $<0.02$ & 614 \\
\hline & $522 \mathrm{~d}$ & $<0.02$ & $<0.02$ & $<0.02$ & 324 & 556 & 549 & 518 \\
\hline & $529 d$ & 381 & 435 & 312 & 340 & 542 & 447 & 436 \\
\hline & 536d & 452 & 457 & 342 & $<0.02$ & $<0.02$ & $<0.02$ & $<0.02$ \\
\hline \multirow{7}{*}{$\mathrm{Al}$} & $10 \mathrm{~d}$ & $<\mathrm{LD}$ & $<\mathrm{LD}$ & $<\mathrm{LD}$ & $<\mathrm{LD}$ & $<\mathrm{LD}$ & $<\mathrm{LD}$ & $<\mathrm{LD}$ \\
\hline & $15 \mathrm{~d}$ & $<\mathrm{LD}$ & 1.528 & $<\mathrm{LD}$ & 1.595 & 1.57 & 2.246 & 367.8 \\
\hline & $172 d$ & $<0.05$ & $<0.05$ & $<0.05$ & $<0.05$ & $<0.05$ & $<0.05$ & $<0.05$ \\
\hline & $515 d$ & $<0.05$ & $<0.05$ & $<0.05$ & $<0.05$ & $<0.05$ & $<0.05$ & $<0.05$ \\
\hline & $522 d$ & $<0.05$ & $<0.05$ & $<0.05$ & $<0.05$ & $<0.05$ & $<0.05$ & $<0.05$ \\
\hline & $529 d$ & $<0.05$ & $<0.05$ & $<0.05$ & $<0.05$ & $<0.05$ & $<0.05$ & $<0.05$ \\
\hline & $536 \mathrm{~d}$ & $<0.05$ & $<0.05$ & $<0.05$ & $<0.05$ & $<0.05$ & $<0.05$ & $<0.05$ \\
\hline \multirow{7}{*}{$\mathrm{Na}$} & $10 \mathrm{~d}$ & $<\mathrm{LD}$ & 6.44 & 2.633 & 15.15 & 7.83 & 15.35 & $<\mathrm{LD}$ \\
\hline & $15 \mathrm{~d}$ & 31.58 & 29.94 & 15.83 & 23.91 & 41.75 & 33.12 & 50.43 \\
\hline & $172 d$ & 14 & 15 & 17 & 13 & 13 & 12 & 4 \\
\hline & $515 d$ & 23.82 & 16.3 & 18.8 & 21 & 19 & 21 & 31 \\
\hline & $522 d$ & 19 & 22 & 22 & 16 & 23 & 18 & 24 \\
\hline & $529 d$ & 17 & 17 & 21 & 16 & 17 & 17 & 19 \\
\hline & $536 \mathrm{~d}$ & 13 & 16 & 17 & 18 & 18 & 19 & 14 \\
\hline \multirow{7}{*}{$\mathrm{Mg}$} & $10 \mathrm{~d}$ & $<\mathrm{LD}$ & 4.39 & 23.495 & $<\mathrm{LD}$ & 20.11 & 40.26 & $<\mathrm{LD}$ \\
\hline & $15 \mathrm{~d}$ & 33.8 & 38.57 & 15.98 & 34.835 & 73.075 & 78.1 & 1894 \\
\hline & $172 d$ & 10.62 & 17.73 & 22.34 & 34.63 & 46.14 & 41.8 & 73.27 \\
\hline & $515 d$ & 13 & 6.41 & 8.08 & 7.8 & 13.74 & 13.91 & 95 \\
\hline & $522 d$ & 17.06 & 19.14 & 15.64 & 22.36 & 26.49 & 41.19 & 95.51 \\
\hline & $529 d$ & 17.54 & 22.5 & 22.92 & 34.34 & 38.04 & 39.23 & 83.9 \\
\hline & 536d & 14.98 & 23.78 & 23.3 & 34.69 & 40.6 & 43.57 & 72.35 \\
\hline \multirow{7}{*}{ K } & $10 \mathrm{~d}$ & $<\mathrm{LD}$ & $<\mathrm{LD}$ & 12.84 & $<\mathrm{LD}$ & 7.13 & $<\mathrm{LD}$ & $<\mathrm{LD}$ \\
\hline & $15 \mathrm{~d}$ & 21.24 & 20.04 & 8.939 & 12.26 & 27.44 & 25.88 & 32.62 \\
\hline & $172 d$ & 17 & 11 & 32 & 42 & 39 & 10 & 7 \\
\hline & $515 d$ & 12.5 & 4.37 & 3.12 & 0.62 & 14.38 & 7.5 & 88 \\
\hline & $522 d$ & 22 & 20 & 36 & 12 & 36 & 14 & 63 \\
\hline & $529 d$ & 51 & 41 & 26 & 42 & 44 & 32 & 32 \\
\hline & $536 \mathrm{~d}$ & 50 & 55 & 43 & 42 & 21 & 35 & 30 \\
\hline \multirow{7}{*}{$\mathrm{Fe}$} & $10 \mathrm{~d}$ & $<\mathrm{LD}$ & $<\mathrm{LD}$ & $<\mathrm{LD}$ & $<\mathrm{LD}$ & $<\mathrm{LD}$ & $<\mathrm{LD}$ & $<\mathrm{LD}$ \\
\hline & $15 \mathrm{~d}$ & $<\mathrm{LD}$ & 0.938 & $<\mathrm{LD}$ & $<\mathrm{LD}$ & $<\mathrm{LD}$ & $<\mathrm{LD}$ & $<\mathrm{LD}$ \\
\hline & $172 d$ & $<0.02$ & $<0.02$ & $<0.02$ & $<0.02$ & $<0.02$ & $<0.02$ & $<0.02$ \\
\hline & $515 d$ & 0.12 & 0.05 & 0.01 & 0.05 & $<0.02$ & $<0.02$ & 1.2 \\
\hline & $522 d$ & $<0.02$ & $<0.02$ & $<0.02$ & $<0.02$ & $<0.02$ & $<0.02$ & 0.73 \\
\hline & $529 d$ & 0.36 & 0.16 & $<0.02$ & $<0.02$ & $<0.02$ & $<0.02$ & $<0.02$ \\
\hline & 536d & 0.76 & 0.23 & 0.12 & $<0.02$ & $<0.02$ & $<0.02$ & $<0.02$ \\
\hline \multirow{7}{*}{$\mathrm{Cu}$} & $10 \mathrm{~d}$ & $<\mathrm{LD}$ & $<\mathrm{LD}$ & $<\mathrm{LD}$ & $<\mathrm{LD}$ & $<\mathrm{LD}$ & $<\mathrm{LD}$ & $<\mathrm{LD}$ \\
\hline & $15 \mathrm{~d}$ & $<\mathrm{LD}$ & $<\mathrm{LD}$ & $<\mathrm{LD}$ & $<\mathrm{LD}$ & $<\mathrm{LD}$ & $<\mathrm{LD}$ & 8.6 \\
\hline & $172 d$ & $<0.02$ & $<0.02$ & $<0.02$ & $<0.02$ & $<0.02$ & $<0.02$ & $<0.02$ \\
\hline & $515 d$ & $<0.02$ & $<0.02$ & $<0.02$ & 0.03 & 0.22 & $<0.02$ & $<0.02$ \\
\hline & $522 \mathrm{~d}$ & 9.81 & $<0.02$ & $<0.02$ & 0.15 & 0.15 & 0.37 & 15 \\
\hline & $529 d$ & $<0.02$ & $<0.02$ & $<0.02$ & 0.06 & 0.17 & 0.17 & 16 \\
\hline & $536 d$ & $<0.02$ & $<0.02$ & $<0.02$ & $<0.02$ & $<0.02$ & $<0.02$ & $<0$ \\
\hline
\end{tabular}

d: Day, < LD : Below the detection limit 
Leachates from columns E1 (CKD as the unique amendment), E2 (amendment composed of $90 \%$ of CKD and $10 \%$ of FA), E3 (tailings mixed with $80 \%$ of CKD and $20 \%$ of FA), E4 (70\% of CKD and 30\% of FA added tailings) and E5 (60\% of CKD and 40\% of FA mixed with tailings) had neutral $\mathrm{pH}$ (6.5 to 7.13) throughout the testing period (Figure 6a). This is due to the high buffering effect of the carbonates included in CKD. Indeed, $\mathrm{pH}$ gradually increases while alkalinity decreases when the content of CKD is high. It is noticed that $\mathrm{pH}$ is very high in column 3. Without the amendment additive, $\mathrm{pH}$ values were very acidic (2.6 to 4, [55]). The presence of CKD in high proportion mixed with the FA (E1 to E5) allows the neutrality of leachate acids and limits the dissolution of metals. These results are in perfect agreement with those found in the literature [52, 53], which showed that the use of CKD in combination with other cementitious materials including fly ash, is more effective [52, 53].

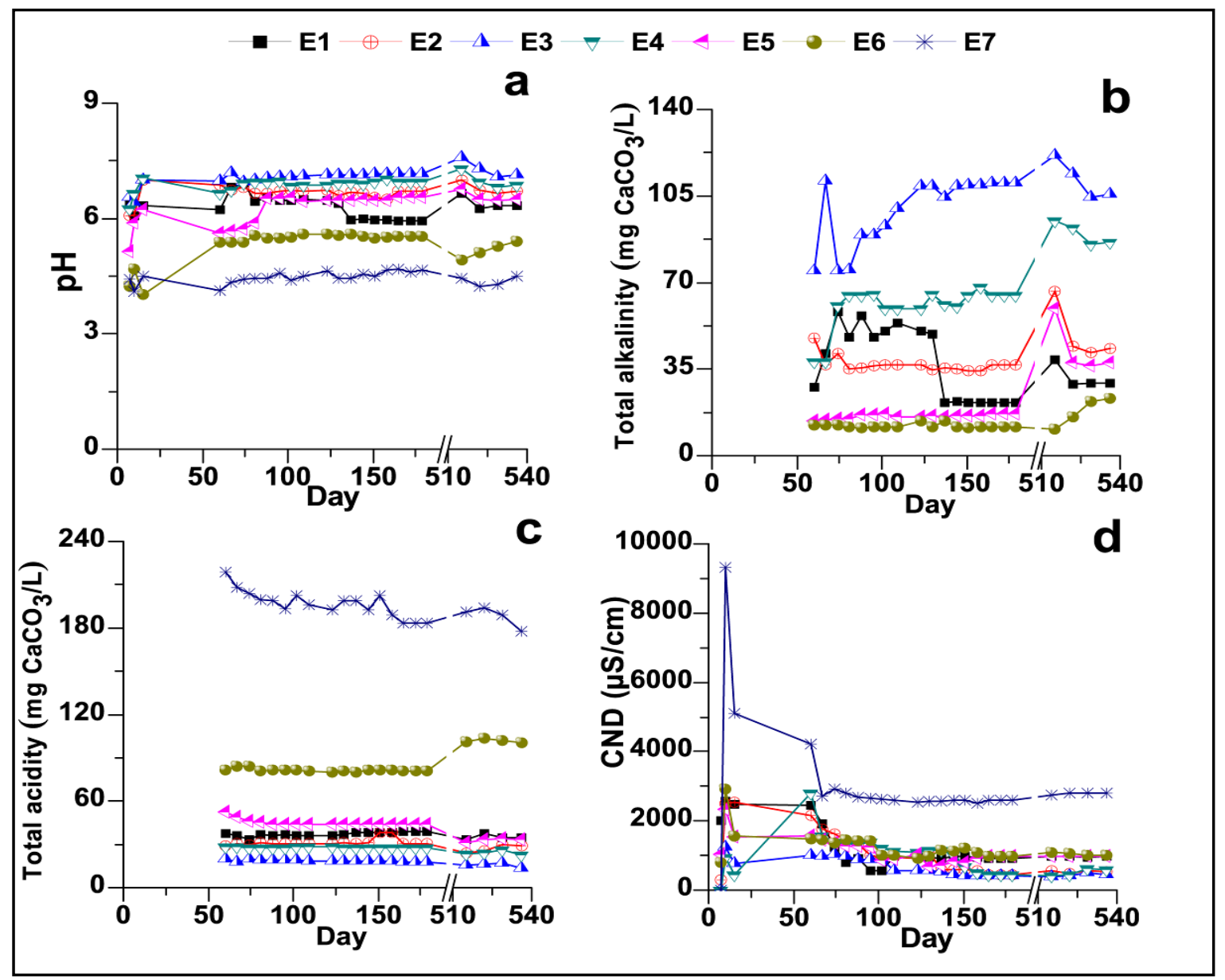

Figure 6: Water quality from the kinetic tests ( $\mathrm{pH}$, electrical conductivity, alkalinity and acidity).

Column E7, filled with Kettara mine tailings mixed with FA only, produced leachates with an acidic $\mathrm{pH}<4.7$ and high values of acidity (between 218.75 and $177.78 \mathrm{mg} \mathrm{CaCO}_{3} / \mathrm{L}$ ) (Figure 6c). These values of acidity are low compared to those obtained from unamendedKettara coarse tailings in humidity cell tests [55]. However, the addition of FA to CKD results increased the neutralization efficiency.

The use only of CKD (E1) as amendment leads to an increase of $\mathrm{pH}$ which does not reach neutrality $(\mathrm{pH}<6.5)$ at the end of the test.

The co-disposal of waste rock and tailings with $10 \% \mathrm{CKD}$ ensures a neutral $\mathrm{pH}$ and reduced concentrations of toxic metals in the short-term solution. This quantity proves insufficient to completely fill the pores of tailings and waste rock [16]. However, Doye [16] noted that it seemed beneficial to add to CKD a small quantity of alkaline industrial wastes, like red bauxite mud (RMB) to the CKD. The RMB, containing a lot of hydroxides, would play the role of a substrate on which metal ions would be adsorbed or coprecipited with iron oxyhydroxides. Indeed, it was found that the mixture CKD + RMB offered a faster neutralization mixture compared to the CKD only. 
The conductivity evolution was similar in the five columns (Figure 6d). Conductivity measurements decreased during the first few cycles (when soluble salts are usually leached) to values between 1244 to $436 \mu \mathrm{S} / \mathrm{cm}$. However, the conductivity values are very high in the column 7 which contains mine tailings mixed only with FA. The conductivity values are mainly due to the dissolved $\mathrm{Ca}^{2+}$, which are present at high concentrations $\left(<0.02 \mathrm{mg} / \mathrm{L}\right.$ to $499.05 \mathrm{mg} / \mathrm{L}$ ) throughout the testing period (Table 1). Alkalinity $\left(\mathrm{HCO}_{3}{ }^{-}+\mathrm{CO}_{3}{ }^{2-}+\mathrm{OH}^{-}\right)$is used as an indicator of the neutralizing capacity of the amendment consisted of CKD and FA. As can be seen in Figure 6b, leachates from column E3 had high levels of dissolved alkalinity, ranging between 74.76 and $105.56 \mathrm{mg}$ $\mathrm{CaCO}_{3} / \mathrm{L}$. Acidity readings were usually less than $20.08 \mathrm{mg} \mathrm{CaCO}_{3} / \mathrm{L}$, indicating thatneutralization processes were important (Figure 6c). Furthermore, alkalinity was practically absent in the leachates of column E7.

Table 1 show that Ca concentrations vary a little in the seven columns. The High Ca concentrations (107- 666.9 $\mathrm{mg} / \mathrm{L}$ ) in the leachates throughout the experiment reflect the rapid neutralization by calcite, which is present in abundance in the CKD. The dissolution of calcite $\left(\mathrm{CaCO}_{3}\right)$, which is the main mineral in the CKD, causes increment of $\mathrm{pH}$, alkalinity, and the concentrations of $\mathrm{Ca}$. The calcium (and other alkalis) of CKD is dissolved and reacts with hydrogen ions in the AMD water, causing its neutralization [57]. The CKD addition produces more Calcium in solution than FA produces; this allows keeping the alkaline environment on the long term. The concentrations in Mg for the six tests (E1, E2, E3, E4, E5 and E6) are low (4.39 to $78.1 \mathrm{mg} / \mathrm{L}$ ) compared to the seventh column (1894 to $72.35 \mathrm{mg} / \mathrm{L}$ ). The Mg observed in the flushed waters may be associated to the chlorite or talc contained in the Kettara coarse tailings [55]. The literature indicates that alkalinity of leachates associated to calcitic limestone dissolution are approximately two greater factors than those of dolomitic limestone [58, 59].

In addition, the Fe concentrations are also low for all seven column leachates, in particular in columns 3, 4 and 5 , suggesting that the adding of CKD considerably increases the $\mathrm{pH}$ and decreases $\mathrm{Fe}$ concentration by the precipitation of hydroxides which control iron solubility. The solubility of ferric components is minimal between $\mathrm{pH} 6$ and 10 and ferric iron is under the form of neutral colloid $\mathrm{Fe}(\mathrm{OH})_{3}$, which constitutes a trap for heavy metals [16]. These columns showed a very low iron concentration (below detection limits); this demonstrates the high capacity of CKD added to limit iron from in solution.

As shown in Table $1, \mathrm{Cu}, \mathrm{K}$ and $\mathrm{Na}$ concentrations were low in the leachate from all seven columns despite the acidic $\mathrm{pH}$ of columns 6 and 7. The $\mathrm{Cu}$ appears in small quantities in the $\mathrm{E} 7$ test but it is below the detection limit (Table 1). Thus, the addition of alkaline material reduced the concentrations of these metals compared to the tailings without amendment [55].

At the beginning of the kinetic test, it was observed that high $\mathrm{Al}$ concentrations in the leachate from the seven columns come most likely from the dissolution of chlorite, muscovite, albite, and talc from the Kettara coarse tailings. After 172 days, these concentrations have become lower than the limit of detection. When alkalinity increases, the $\mathrm{Fe}$ and $\mathrm{Al}$ precipitate out of the water solution at $\mathrm{pH}$ levels of 6 to 8 , while other ions can precipitate at higher $\mathrm{pH}$ values [57].

In general, the tests 6 and 7 are not effective for the control of the AMD because their $\mathrm{pH}$ remains acid $(\mathrm{pH}<5.5)$ and their conductivity is very high (between 991 and $2797 \mu \mathrm{S} / \mathrm{cm}$ ).

\section{Hydraulic analysis in the laboratory}

The permeability of the mixture amended (2/3) of tailings and (1/3) of industrial waste, $80 \%$ of CKD and $20 \%$ $\mathrm{FA}$, is of the order of $4.4 .10^{-6} \mathrm{~cm} / \mathrm{s}$. This mixture leads to a decrease the tailings permeability and reduced the effect of acid drainage waters. This permeability was calculated using Darcy's law [50].

\section{Conclusions}

The main objective of this study is to evaluate the capacity of alkaline industrial by-products to control AMD generated from coarse tailings of Kettara. The main focus was on the process of amendment based cement kiln dust (CKD) mixed with fly ash (FA).

The physicochemical properties and hydraulic CKD and FA predispose them to be use as amendment in order to stabilize the tailings and to protect water resources, flora and fauna [30]. The column kinetic tests have been carried out in the laboratory to determine the quantity of alkaline material required to obtain long-term neutralization of reactive tailings.

The tests E6 and E7 have not reduced the AMD effectively because their $\mathrm{pH}$ remained acid. Their conductivity is very high and the percolation time is very short. It is also clear that only of CKD (E1) or FA (E7) based amendment is less active for neutralization of leachate in comparison with their blend (E3). 
The comparison of the seven columns show that the amendment with CKD in strong proportion (E1-E5) is more effective for the neutralization of acid leachate but the mixture of $80 \%$ CKD and $20 \%$ FA (E3) remains the most suitable. This test (E3) is characterized by a neutral $\mathrm{pH}$, the lowest conductivity and permeability.

The use of $\mathrm{CKD}$, containing highly reactive soluble $\mathrm{CaO}$, uniquely as amendment leads to $\mathrm{pH}$ increase that does not reach neutrality $(\mathrm{pH}<6.5)$ but the addition of a small quantity of $\mathrm{FA}$ is more effective for the neutralization of tailings in view of its chemical and mineralogical properties making the ash a good alkaline binding agent. The addition of FA causes an increase of the neutralization efficiency limiting the dissolution of metals and reduces water infiltration. The mixture of the CKD and FA reduces the diffusion of water and oxygen and triggers the formation of ettringite and gypsum which precipitate metals and consequently enabling the control of AMD.

Acknowledgments The authors wish to thank the granting agencies of this study; in particular the International Research Chairs Initiative, a program funded by the International Development Research Centre (IDRC) and Canada Research Chairs program (Canada), the National Center for Scientific and Technical Research (CNRST, Rabat), Cement Lafarge and the Central Heat of JorfLasfar, Laboratory of Chemistry of the Materials and Environment (FST, Marrakech), Geology Laboratory of Applied, Geomatics and Environment (FSBM, Casablanca).

\section{References}

1. Blowes D.W., Ptacek C.J., US Patent, Washington DC. N 5 (1994) 362,394.

2. Evangelou V.P., Zhang Y.L., Environ. Sci. Technol. 25 (1995) 141-199.

3. Kleinman R.P.L., Crerar D.A., Pacelli R.R., Min. Eng. 33 (1981) 300-306.

4. Ouakibi O., Loqman S., Hakkou R., Benzaazoua M., Mine. Water. Environ. 32 (2013) 7-10.

5. MEND, Manual. Report. 5.4.2. 1-5 (2001).

6. Aubertin M., Bussière B., Bernier L., Chapuis R., Julien M., Belem T., Simon R., Mbonimpa M., Benzaazoua M., Li L., Ann. Confer. Canad. Soc. Civ. Eng. (2002) 6.

7. Bussière B., Benzaazoua M., Aubertin M., Mbonimpa M., Environ. Geo. 45 (5), (2004) 609-622.

8. Dagenais A. M., Aubertin M., Bussière B., Cyr G., Fontaine R., Symp. Environ. Min. (2003).

9. Bussière B., Lelièvre J., Ouellet J., Bois D., Proc. Sudbury'95, Conf. Min. Environ. 1 (1995) 59-68.

10. Bussière B., Benzaazoua M., Aubertin M., Lelièvre J., Bois D., Servant S., Rap. Fin. min. Res. Natur. (1998a) 198.

11. Benzaazoua M., Bussière B., Lelièvre J., 30th Canad. Miner. Process. Symp., (1998) 682-695.

12. Benzaazoua M., Bussière B., Kongolo M., Mclaughlin J., Marion P., Int. J. Miner. Process. 6 (2000) 57-74.

13. Benzaazoua M., Kongolo M., Int. J. Miner. Process. 69 (2003) 221-234.

14. Bois D., Benzaazoua M., Bussière B., Kongolo M., Poirier P., CIM Bul. 98 (2005) 74.

15. Mermillod-Blondin R., Kongolo M., De Donato P., Benzaazoua M., Barrès O., Bussière B., Aubertin M., Cent. Flot. Symp., Brisbane, QLD (2005).

16. Doye I., Ph.D.,Fac. Sci. Génie, U.L. (2005) 29 -31, 145-151.

17. Hakkou R., Benzaazoua M., Bussière B., Mine. Water. Environ. 28 (2009) 5-6.

18. González V., García I., Del Moral F., Simón M., J. Hazard. Mat. 205-206 (2012)72-80.

19. Ritcey G.M., Elsev., New York City. 6 (1989) 970.

20. Perry E.F., Brady K.B., Proc. $16^{\text {th }}$ ann. Surf. Min. Drain. Task force symp. (1995).

21. Rose A.W., Phelps L.B., Parizek R.R., Evans D.R., Proc., Twelfth Amer. Soc. Surf. Min. Recl. Confer. (1995).

22. Ayala J., Blanco F., Garcia P., Rodriguez P., Sancho J., Fuel 77 (1998) 1147-1154.

23. Brake S.S., Jensen R.R., Mattox J.M., Environ. Geol. 45 (2003) 680-689.

24. Dermatas D., Meng X., Engine. Geo. 70 (2003) 377-394.

25. Pérez-López R., Nieto J.M., Almodóvar G.R., Proc. 9th I.M.W.A. (2005) 5-10.

26. Pérez-López R., Nieto J.M., Almodóvar G.R., App. Geoch. 22(2007) 1919-1935

27. Bertocchi A.F., Ghiani M., Peretti R., Zucca A., J. Hazard. Mat. 134 (2006) 112-119.

28. Yeheyis M.B., Shang J.Q., Yanful E.K., J. Environ. Eng. Sci., 7 (2008) 481-498.

29. Alakangas L., Andersson E., Mueller S., Environ. Sci. Pollut. Res. 20 (2013) 7907-7916.

30. Nfissi S., Alikouss S., Zerhouni Y., Hakkou R., Benzaazoua M., Samir M., Baroudi Z., Int. J. Geo. Earth Environ. Sci. 4 (2014) 51-61.

31. Mehling P.E., Day S.J., Sexsmith K.S., Proc. Fourt. Int. Confer. A.R.D. 2 (1997) 951-969.

32. Lapakko K.A., Antonson D.A., Wagner J.R., Proc. Fifth Int. Confer. A.R.D. 2 (2000) 901-910. 
33. Chtaini A., Thèse doct. éssci. Appl. (Ph.D),Univer. Sherbooke, FacGénie, (1999) 5-6, 19-28.

34. Addou R., Hannawi K., Agbodjan W.P., Zenasni M., J. Mater. Environ. Sci., 8 (2017) 3474.

35. Bossé B., Bussière B., Hakkou R., Maqsoud A., Benzaazoua M., Mine. Water. Environ., 32 (2013) 5-6.

36. Huvelin P., Not. et Mém. Serv. Géol. Maroc, 232b, (1977) 1-307.

37. Renaud P., Essai M. Sc. (1994) 114.

38. Duchesne J., Reardon E.J., Wast. Manag. 18 (1998) 339-350.

39. Fortin S., Lamontagne A., Poulin R., Tasse N., Proc. $6^{\text {th }}$ int. Confer. Environ. Iss. Manag. wasteenergy. Miner. prod. (2000) 549-556.

40. Bellaloui, A., Tagnit-Hamou, A., Ballivy, G., Press. Sci. CNRC. 39 (2002) 960-970.

41. Rhouzlane S., Thèse doct. ès sci. Appl. (Ph.D.). Univer. Sherbrooke, Fac. Sci. Appliq. (1997).

42. Huvelin P., Not. et Mém. Serv. Géol. Maroc, 232b. (1972).

43. Yahyaoui L., Essaifi A., Not.et Mém. Serv. Géol. Maroc, $n^{\circ}$ 563. (2011) 75.

44. Bossé B., Ph.D. Diss., UQAT., Canada (2013).

45. Khalil A., Hanich L., Bannari A., Zouhri L., Pourret O., Hakkou R., Geoch. Expl. 125 (2013) 125-126.

46. Hakkou R., Benzaazoua M., Bussière B., Mine. Water. Environ. 27 (2008) 146-154.

47. Lghoul M., Kchikach A., Hakkou R., Zouhri L., Guerin R., Bendjoudi H., Teíxido T., Penã J.A., Enriqué L., Jaffal M., Hanich L., Hydr. Sci. J. 57(2) (2012) 378-380.

48. Nfissi S., Zerhouni Y., Benzaazoua M., Alikouss S., Chtaini A., Hakkou R., Samir M., Ann. Soc. Géol. Nord.T. 18 (2011) 43-53.

49. EL moudni El alami S., Monkade M., Phys. Chem. News 51(2010) 38-44.

50. Nfissi S., Thèse Doct., FSBM. U.H.II.C., Morocco (2013).

51. Ballivy G., Rouis J., Breton D., Cemt. Ind. Solt. WasteManag. (1992).

52. Adaska W.S., Taubert D.H., 50 ${ }^{\text {th }}$ Cemt. Ind. Tech. Conf. Rec. (2008) 12-16.

53. Nehdi M., Tariq A., Miner. Metall. Proc. 25 (2008) 185-198.

54. Bouzahzah H., Thèse Doct., U.Q.A.T., Canada (2013) 288.

55. Hakkou R., Benzaazoua M., Bussière B., Mine. Water. Environ. 27 (2008) 161-163.

56. APHA (American Public Health Assoc), $19^{\text {th }}$ edn. Amer. Pub. Healt. Assoc. (1995).

57. Ekolu S.O., Azene F., Environ Sci Tech 2. Amer. Sci. Press. (2012) 27-33.

58. Cravotta C.A.III., Ward S.J., Hammarstrom J.M., Mine. Water. Environ. 27 (2008) 86- 99.

59. Genty T., Bussière B., Potvin R., Benzaazoua M., Post-Min. (2008).

\section{(2017); ;ttp://www.jmaterenvironsci.com}

